\section{British-German collaboration agreed \\ Munich}

A NEW programme to promote research collaboration between West German and British institutes of higher education has been launched by the British Council and the German Academic Exchange Service (Deutscher Akademischer Austausch Dienst or DAAD). The programme will

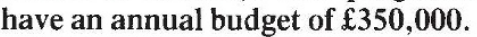

The programme, entitled the Academic Research Collaboration, will support 80 multi-year projects in science, engineering and business studies undertaken by researchers in British universities and polytechnics and in West German universitites and Fachhochschulen. The intention is to provide several members of a research group with the chance to work in the other country.

The Anglo-German Foundation for the study of Industrial Society, based in London, will provide an additional $£ 30,000$ in 1989 for collaborative research in the social sciences. The British Council office in Cologne will handle applications from British researchers; the DAAD headquarters in Bonn will handle applications from West Germany.

Steven Dickman

SCIENCE JOURNALS

\section{What's in a name?}

\section{Paris}

THE decision of the Pasteur Institute to give its journal of microbiology, virology and immunology an English title is continuing to create protest in the correspondence columns of the national newspaper $L e$ Monde, to the exasperation of the institute's director, Maxime Schwartz (see Nature 338, 448; 6 April 1989). The venerable Academie Française condemned the decision outright, the distinguished scientist Axel Kahn called the move "suicidal", and even President François Mitterrand asked for an explanation.

But most vociferous have been Canadian scientists from Quebec, proud of their success in keeping French alive against all odds. "If the French abandon their mothertongue", said an irate Canadian at a press conference last week, "what hope is there for us or for African countries?" Obviously tired of repeating himself, Schwartz politely pointed out that out of the 2,500 subscriptions, only about 75 were from Canada and fewer than 10 from Quebec.

Research Minister Hubert Curien told Nature that the affair had grown out of proportion, asking that the French set an example to other nations by speaking French "out of love for the language, not out of laziness". Meanwhile, the Pasteur Institute stands firm on its decision but plans to publish a new review in French with original scientific notes.

Peter Coles

\title{
Soviets readmitted to WPA
}

\section{London}

THE Soviet psychiatric establishment has been provisionally readmitted to membership of the World Psychiatric Association (WPA) pending the WPA's six-yearly congress in Athens next October. The Soviet All-Union Society of Psychiatrists and Neuropathologists resigned from the WPA in 1983, anticipating motions for its expulsion on the agenda of the WPA Congress in Vienna that year. At the 1983 congress, it was understood that the Soviet psychiatrists would be welcome to apply for readmission if and when they gave sufficient proof that the systematic use of psychiatric methods for the repression of sane political dissidents and religious believers had ceased in the Soviet Union. The Soviet psychiatrists now maintain that this condition has been met. A number of Western psychiatric associations, including the Royal College of Psychiatrists in Britain and the West German Deutsche Gesellschaft für Psychiatric und Nervenheilkunde, maintain that their readmission would be dangerous and premature.

The provisional reinstatement of the Soviet organization was sponsored by the president of the WPA, Dr Costas Stefanis, and its general secretary, Dr Fini Schulsinger, who invited two Soviet representatives to attend a recent meeting of the European regional executive of the WPA in Granada. After speeches from these visitors, one of whom, Dr Nikolai Zharihov, maintained that the Soviets had now mended their ways, while the other, Dr Protr Morozov, claimed that there had never been any misuse of psychiatry anyway, Stefanis and Schulsinger pushed through the motion of reinstatement, over the protests of those executive members who felt it would be more appropriate to wait for the report of the recent fact-finding and 'verification' mission of US psychiatrists to the Soviet Union.

The motion of reinstatement contravened a number of procedural rules of the WPA. In particular, the application for readmission (which according to rule had to be filed a year before the next congress) was filed by the All-Union Soviet of Psychiatrists and Neuropathologists. Shortly afterwards, however, the neuropathologists seceded from this society and set up their own organization, while their place was taken by the narcologists, so that the organization which was provisionally admitted to the WPA in Granada - the All-Union Society of Psychiatrists and Narcologists - was not, formally speaking, the same organization that had applied last October.

This technicality acquired more than a formal significance, as Stefanis and Schulsinger told the executive meeting that they had rejected out of hand the application for membership of the new unofficial Association of Independent Psychiatrists established in Moscow last month, on the grounds that its application had come too late for consideration at the next WPA Congress

Technicalities apart, the main issue is whether the official Soviet psychiatric profession has mended its ways. In spite of high-sounding legal commitments, the handing over of the administration of the former special psychiatric hospitals from the jurisdiction of the police to the Ministry of Health and some press articles deploring the occasional "hyper-diagnosis" of dissidents during the Brezhnev era, the Netherlands-based International Association on the Political Use of Psychiatry has collated an impressive body of evidence suggesting that patients are still being held in Soviet psychiatric hospitals on political grounds.

The promised report of the US factfinding mission, which it is now said will not be ready until June, seems unlikely to clarify the issue. There seems to have been an agreement between the US visitors and their Soviet hosts that neither side will make statements to the media based on the results of this mission. The Soviet side has in fact already breached this agreement, by claiming that the US experts found that all was well with the Soviet psychiatric practice - a statement which many of the visitors maintain did not reflect their views.

Vera Rich

\section{NUCLEAR DECOMMISSIONING}

\section{MPs criticize delay}

\section{London}

THE decommissioning policy of Britain's nuclear industry was severely criticized by the House of Commons Energy Committee last week. After examining the annual report and accounts of British Nuclear Fuels Limited, the committee says the decision to postpone decommissioning of nuclear plans for 50 to 100 years after closure may have been adopted in order to bolster the company's short-term profits, and it is sceptical of the company's denials. The committee suggests that the Nuclear Installations Inspectorate be asked to assess whether there are any safety, environmental or technical reasons for postponing decommissioning for longer than 20 or $\mathbf{3 0}$ years. The committee directs the same criticism at the electricity boards, and says the government should clarify how the costs of decommissioning nuclear power stations would be met if these boards, soon to be privatized, went into liquidation.

Christine McGourty 